\title{
Assessment of several advanced oxidation processes applied in the treatment of environmental concern constituents from a real hair dye wastewater
}

\author{
Guilherme Garcia Bessegato*, João Carlos de Souza, Juliano Carvalho Cardoso, \\ Maria Valnice Boldrin Zanoni* \\ Universidade Estadual Paulista (Unesp), Instituto de Química, Araraquara. Av. Prof. Francisco Degni, 55, 14800-060, Araraquara, SP, Brazil
}

\section{A R T I C L E I N F O}

\section{Keywords:}

Degradation

Permanent hair dye

Ozonation

p-Phenylenediamine

Bandrowski's base

Resorcinol

\begin{abstract}
A B S T R A C T
Currently, little information is available regarding the presence of compounds from raw hair dyeing wastewater. It is known that the most commonly commercial formulations contain components with toxic properties and some by-products may also be mutagenic and carcinogenic. Indeed, virtually no studies can be found in the literature dealing with the treatment of such effluents and identification of environmental concerning substances, such as p-phenylenediamine, resorcinol and Bandrowski's base. The present work sought to evaluate the treatment of real hair dyeing effluent through different combinations of advanced oxidation processes including ozonation $\left(\mathrm{O}_{3}\right)$, ozone/UV-C $\left(\mathrm{O}_{3} / \mathrm{UV}\right)$, ozone/photoelectrocatalysis $\left(\mathrm{O}_{3} / \mathrm{PEC}\right), \mathrm{O}_{3} / \mathrm{UV} / \mathrm{H}_{2} \mathrm{O}_{2}$ and $\mathrm{O}_{3} / \mathrm{PEC} / \mathrm{H}_{2} \mathrm{O}_{2}$. $\mathrm{O}_{3} / \mathrm{PEC} / \mathrm{H}_{2} \mathrm{O}_{2}$ combination provided almost complete mineralization while ozonation promoted less than $50 \%$ after $90 \mathrm{~min}$ of treatment. HPLC analysis confirmed the presence of $p$-phenylenediamine, resorcinol and Bandrowski's base in the raw effluent, which were completely removed in less than 5 min of treatment through the application of the combined $\mathrm{O}_{3} / \mathrm{PEC} / \mathrm{H}_{2} \mathrm{O}_{2}$ process. A figure of merit, the electric energy per order, was used to compare the different methods, showing that $\mathrm{O}_{3} / \mathrm{PEC} / \mathrm{H}_{2} \mathrm{O}_{2}$ provides lower energy consumption and higher mineralization, and could thus be an efficient option for wastewater treatment.
\end{abstract}

\section{Introduction}

People have an inherent desire to improve their appearance, and hair dyes formulations play an important role in improving the quality of life. In the US, $42 \%$ of women and $25 \%$ of men use hair dyes, while in Brazil $26 \%$ of adults use hair dye, most of whom are women $[1,2]$. Usually, 70\% of hair dye formulations used at home and in hair salons are based on permanent dyes, which offer high diversity of coloration, long permanence effect, ease of application and versatility [3,4]. Permanent hair dyes are made from reactions between a 'primary intermediate' (e.g. p-phenylenediamine (PPD)) and 'couplers' (or modifiers) (e.g. resorcinol (RSC)) in the presence of an oxidant (e.g. hydrogen peroxide) in alkaline media (e.g. ammonia) [5-8], where dyes are formed after diffusion to the cortex of the strand of hair. These reactions are discussed in detail in the literature $[3,5,8]$. The main pathways for the PPD and RSC reactions are described in Fig. 1.

Notwithstanding the successful, ample commercialization of this kind of dyes, the prevailing huge concerns with respect to their composition need not be overemphasized $[3,5,6,9]$. Acute toxicity tests show that all major hair dye ingredients, such as PPD and RSC, have either moderate or low acute toxicity properties [5]. Nearly $99 \%$ of hair color formulations contain at least one potent sensitizer, of which PPD and RSC are present in $78 \%$ and $89 \%$ respectively [10]. Reports in the literature have also demonstrated that intracellular increase in reactive oxygen species generated through the oxidation of PPD is cytotoxic to $\mathrm{HaCaT}$ cells and that this mechanism induces DNA damage [6]. Furthermore, PPD may be oxidized in the presence of air or via the oxidant present in the formulation, generating the Bandrowski's base (BB), which is a mutagenic [6,11] sensitizer and a genotoxic by-product $[5,12,13]$. In addition, due to their chemical structures, these compounds are likely to bioaccumulate and have long-term effects on aquatic organisms [14-16]. In this context, wastewater from hair dyeing has been drawing considerable attention, since a great quantity of these precursors, couplers and dyes (products of reactions), as well as Bandrowski's base (an undesirable sub product) are lost during hair washing after the coloring process and are released in domestic and salon effluents $[15,17]$. Clearly, the treatment of these effluents is a subject of huge environmental and public health concern.

In most countries, wastewater is treated using biological processes by aerobic microorganisms. When there is knowledge about the formation of biocalcitrant compounds, then anaerobic microorganisms, slow aggregate filtration systems, adsorption, and reverse osmosis make

\footnotetext{
* Corresponding authors.

E-mail addresses: guilhermebessegato@gmail.com (G.G. Bessegato), boldrinv@iq.unesp.br (M.V.B. Zanoni).
} 


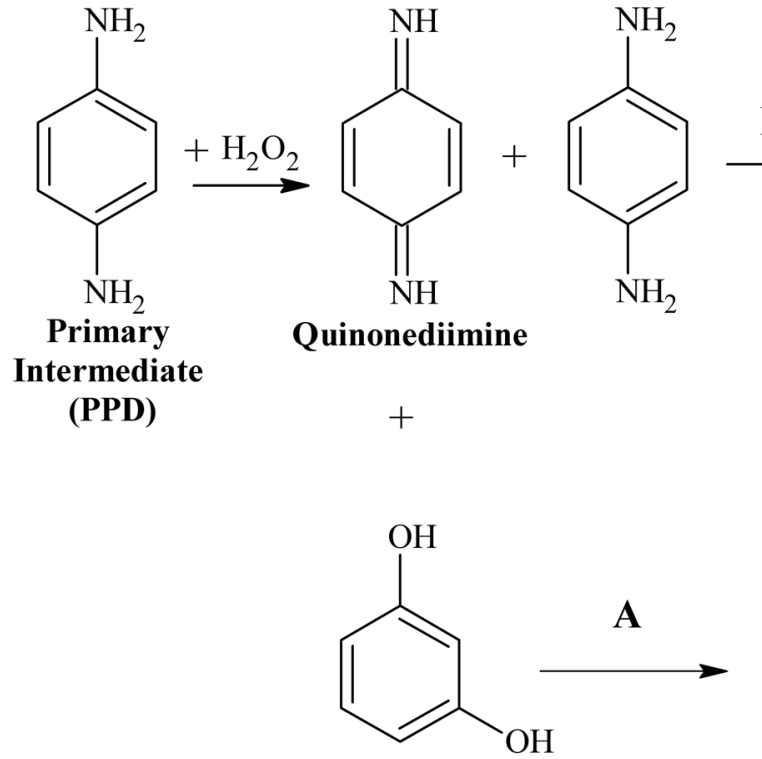

Coupler (RSC)
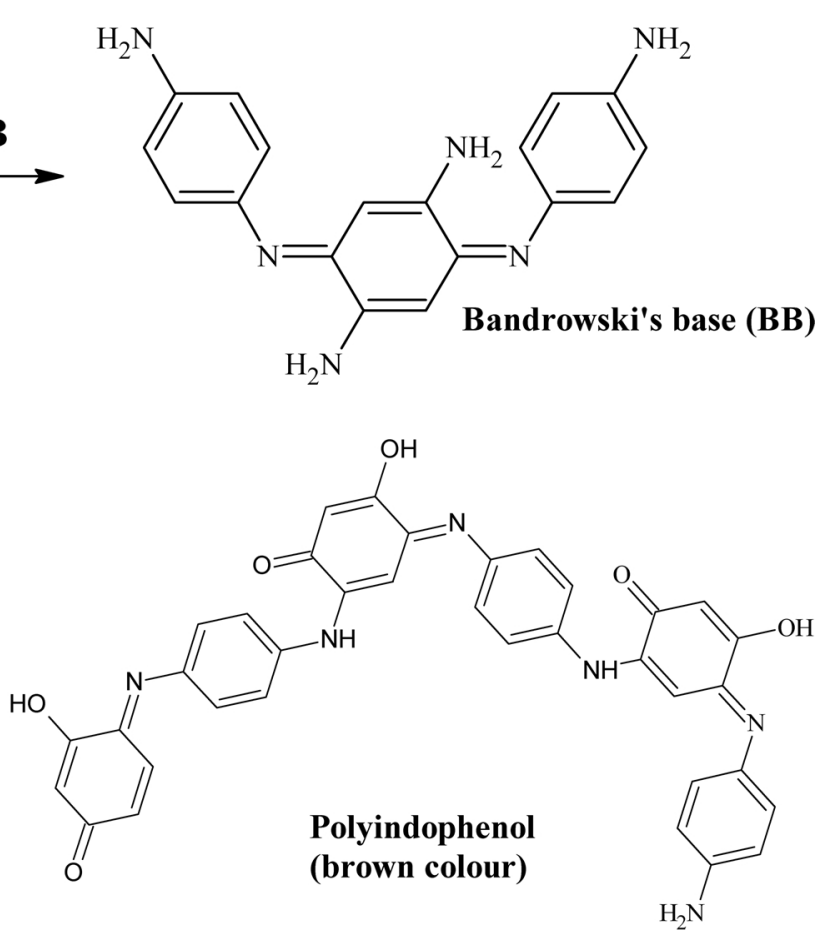

Fig. 1. Chemical pathways for PPD: (A) in the presence of RSC in alkaline media containing $\mathrm{H}_{2} \mathrm{O}_{2}$ to form the hair dye (polyindophenol); and (B) in the absence of RSC (or other couplers), which leads to the formation of Bandrowski's base.

Adapted from Nohynek et al. [38] and Shah et al. [8].

up the other most commonly used processes [18-21]. By virtue of the great diversity of hair salons effluents coupled with the difficulty encountered in treating them, the current treatment mechanisms applied towards addressing wastewater pollution are still far from satisfactory with respect to the established guidelines of the Environmental Protection Agency [22,23]. In general, there is limited knowledge regarding the presence of pollutants and wastewater treatment technologies for small-scale wastewater such as hair salon effluents.

The use of photoelectrocatalytic oxidation (PEC) as a strategy for promoting the degradation of hair dyes has been investigated in the last few years [24-26]. Hydroxyl radical is formed through water oxidation on $\mathrm{TiO}_{2}$ surface when irradiated by UV light (photocatalysis). The efficiency of this reaction can be enhanced when $\mathrm{TiO}_{2}$ electrode is under a potential superior to its flat band potential, a process commonly referred to as photoelectrocatalysis [27]. With regard to highly concentrated solutions, the treatment of a hair dye solution (100-1000 $\left.\mathrm{mg} \mathrm{L}^{-1}\right)$ via photoelectrocatalysis requires the combination of the process with ozonation [24], which culminates in the formation of greater amount of hydroxyl radicals $(\cdot \mathrm{OH})$, enhancing total organic carbon removal and reducing energy consumption. Ozone is also a powerful oxidant $(2.07 \mathrm{~V} v s 2.8 \mathrm{~V}$ for $\cdot \mathrm{OH})$ and can react with organic pollutants via direct attack, which is selective and relatively slow. $\mathrm{O}_{3}$ cannot mineralize some organic compounds such as inactivated aromatics or saturated carboxylic acids. $\mathrm{O}_{3}$ can also act via an indirect pathway where $\cdot \mathrm{OH}$ radicals are produced by ozone decomposition, which is also an advanced oxidation process (AOP) [28].

To the best of our knowledge, there have been few works reported in the literature dealing with the treatment of hair dyeing effluents $[29,30]$. Surprisingly, studies on advanced oxidation processes aiming at the treatment of this kind of effluents are lacking in the literature. In addition, neither analytical data regarding the identification of compounds present in the wastewater nor works focusing on detecting the presence of the hazardous $\mathrm{BB}$ contaminants in the wastewater are available.

The present work sought to compare the efficiency of some treatment methodologies including ozone alone $\left(\mathrm{O}_{3}\right)$; ozone combined with
UV light $\left(\mathrm{O}_{3} / \mathrm{UV}\right)$ along with the addition of $\mathrm{H}_{2} \mathrm{O}_{2} \mathrm{O}_{3} / \mathrm{UV} / \mathrm{H}_{2} \mathrm{O}_{2}$; ozone combined with photoelectrocatalysis $\left(\mathrm{O}_{3} / \mathrm{PEC}\right)$; and ozone in the presence of hydrogen peroxide $\left(\mathrm{O}_{3} / \mathrm{PEC} / \mathrm{H}_{2} \mathrm{O}_{2}\right)$. For the purpose of conducting the above-mentioned treatment mechanisms, a versatile annular bubble photoelectrocatalytic reactor was used so as to ascertain the best alternative suitable for the treatment of hair dyeing effluent. The presence of target compounds including PPD, RSC and BB, before and after treatment, was analyzed through the development of a liquid chromatography method. The economic aspects of the reactor were evaluated by the figure of merit 'electric energy per order' $\left(E_{\mathrm{EO}}\right)$ (the electric energy required for degrading a contaminant by an order of magnitude in a unit volume) [31].

\section{Experimental}

\subsection{Hair dyeing wastewater analysis}

Wastewater samples were collected in polypropylene bottles of $20 \mathrm{~L}$ storage capacity in hair salon sewage following a hair dyeing process. The hair dye formulation (dark brown color) had been applied to the hair according to the label instructions, left to act for $40 \mathrm{~min}$ followed by subsequent washing of the hair with tap water until complete removal of the unfixed dye. The wastewater samples were stored at $-5{ }^{\circ} \mathrm{C}$ when not used within $48 \mathrm{~h}$ of collection. The following physicochemical parameters of the collected wastewater were monitored: $\mathrm{pH}$ (pHmeter Tecnopon, mPa 210 model), conductivity (multiparameter pHtek ${ }^{\oplus} \mathrm{CD}$ 8B), turbidity (portable turbidimeter Quimis Q279P), color (mg PtCo/ L) (colorimeter Hanna Instruments HI83200), chemical oxygen demand (COD) (Macherey-Nagel ${ }^{\circ}$ PF-3) and total organic carbon (TOC) (Shimadzu TOC-V $\mathrm{V}_{\mathrm{CPN}}$ model).

The presence of PPD, RSC and BB in the effluent was assessed through the development of a liquid chromatography method using diode array detection (HPLC-DAD (UV-vis)) and taking standard samples of each analyte. The effluent sample that was intended to be used for HPLC-DAD analysis was centrifuged ( $800 \mathrm{rpm}$ for $2 \mathrm{~min}$ ) and the supernatant was then removed and vacuum filtered in a $0.47 \mu \mathrm{m}$ filter. 
Subsequently, $95 \mathrm{~mL}$ of the sample was eluted in a solid phase extraction cartridge ( $500 \mathrm{mg}$, Phenomenex Strata X). The retained content was recovered with $5 \mathrm{~mL}$ of methanol and preconcentrated to $0.5 \mathrm{~mL}$ by evaporation with $\mathrm{N}_{2} .0 .3 \mathrm{~mL}$ of Milli-Q water was then added to the concentrated extract and the volume was adjusted to $1.0 \mathrm{~mL}$ by the addition of methanol aiming at obtaining $30 \%$ of water content. The sample was then again filtered through a $0.22 \mu \mathrm{m}$ filter and an aliquot of $20 \mu \mathrm{L}$ was injected into the HPLC (Shimadzu, LC-10AT model). The separation column employed was an Eclipse ${ }^{\circ}$ ADB C18 $(5 \mu \mathrm{m}$, $15 \mathrm{~cm} \times 4.6 \mathrm{~mm}$ ) reverse phase column, preceded by a pre-C18 reversephase cartridge (guard column). The mobile phase consisted of acetate buffer of $0.1 \mathrm{~mol} \mathrm{~L}^{-1}$ (pH 5.6) and methanol. Here, we adopted a gradient of $97 \%$ : 3\% (acetate buffer: methanol) for $3.7 \mathrm{~min}$, then $90 \%: 10 \%$ (acetate buffer:methanol) for $20 \mathrm{~min}$ at a flow rate of $0.80 \mathrm{~mL} \mathrm{~min}^{-1}$. It is worth pointing out that this method was adapted from the work of [32]. RSC and PPD were detected at $279 \mathrm{~nm}$ and BB at $413 \mathrm{~nm}$.

The identification of PPD, RSC and BB in the hair dyeing sample was confirmed by comparing the retention times and the UV/Vis spectra with those obtained with a standard solution of PPD, RSC and BB. The standard solution contained $10 \mathrm{mgL}^{-1}$ of RSC and $10 \mathrm{mg} \mathrm{L}^{-1}$ of PPD (30\% water, $70 \%$ methanol). This solution was injected into the HPLC following the same elution conditions. In order to obtain the BB intermediate, $1000 \mathrm{mg} \mathrm{L}^{-1}$ of PPD solution in ammonia buffer (pH 8) with $1 \%$ of hydrogen peroxide was kept in the presence of oxygen for $40 \mathrm{~min}$ as described in previous work [7]. Afterwards, $50 \mathrm{~mL}$ of the reaction mixture was then eluted in a solid phase extraction cartridge following the same procedure applied for the preparation of the hair dyeing effluent sample.

\subsection{Preparation of the $\mathrm{TiO}_{2} \mathrm{NT}$ cylindrical electrode}

For the photoelectrocatalytic (PEC) experiments, a cylindrical $\mathrm{TiO}_{2}$ nanotube array electrode $\left(\mathrm{TiO}_{2} \mathrm{NT}\right)$ was constructed. The electrode was constituted of $600 \mathrm{~cm}^{2}$ geometric area and a lateral opening for the flow of solution (Fig. 2a). The $\mathrm{TiO}_{2} \mathrm{NT}$ was prepared in line with reports in the literature [33]. A Ti sheet of $35 \times 17 \mathrm{~cm}(0.5 \mathrm{~mm}$ thickness) was previously polished and cleaned. The titanium foil was shaped into cylindrical form and $\mathrm{TiO}_{2}$ nanotubes were grown by electrochemical anodization ( $30 \mathrm{~V}$ for $50 \mathrm{~h}$ using Minipa MPL-1303 power supply) in a two-electrode cell using a dimensionally stable anode (De Nora ${ }^{\circ}$ ) sheet as a counter electrode. The electrolyte was composed of $0.25 \% \mathrm{NH}_{4} \mathrm{~F}$ in glycerol $(90 \%)$ /water $(10 \%)$. The $\mathrm{Ti} / \mathrm{TiO}_{2} \mathrm{NT}$ electrode was annealed at $450{ }^{\circ} \mathrm{C}$ for $30 \mathrm{~min}$ (heating rate of $2^{\circ} \mathrm{C} \mathrm{min}^{-1}$ ).

\subsection{The reactor for hair salon wastewater treatment}

The experiments were performed in an annular bubble reactor (ABR) of $63.5 \mathrm{~mm}$ diameter, having a capacity of $1.3 \mathrm{~L}$ (Fig. 2b), equipped with sintered glass bubblers at the bottom for injecting $\mathrm{O}_{2} / \mathrm{O}_{3}$ and operating in batch regime kept under recirculation at a rate of $1060 \mathrm{~mL} \mathrm{~min}^{-1}$ controlled by a peristaltic pump (Cole-Parmer, model Masterflex L/S 7518-10) with Viton tubing.

For the experiments involving irradiation, an UV-C $36 \mathrm{~W}$ lamp (Osram) was inserted at the center of the reactor and a cylindrical electrode of $\mathrm{Ti} / \mathrm{TiO}_{2} \mathrm{NT}$ was placed around the lamp. Two graphite rods (diameter $1.0 \mathrm{~cm}$ ) were used as cathodes (Figs. 2b, c). The bias voltage of $2.5 \mathrm{~V}$ was controlled using a Minipa PL-1303 power supply. Ozone was produced by an $\mathrm{O}_{3} \mathrm{R}^{\oplus}$ ozonator model ID-05 (Brazil) using dry oxygen as the feed gas $(99.9 \%$ purity). The ozone input rate of $3.85 \times 10^{-4} \mathrm{~mol} \mathrm{~min}^{-1}$ was delivered at $\mathrm{O}_{2}$ flow rate of $1.0 \mathrm{~L} \mathrm{~min}^{-1}$ monitored with a Cole-Parmer flowmeter $\left(0.4-5.0 \mathrm{~L} \mathrm{~min}^{-1}\right)$. The amount of ozone generated was determined through the use of an ozone analyzer Anseros GM-OEM ( $254 \mathrm{~nm}$ radiation). For all the experiments, aliquots of $15 \mathrm{~mL}$ solution were taken out at a pre-determined time and subjected to analysis. All the experiments were performed in an isolated laboratory and inside a fume cupboard with excellent exhaustion.

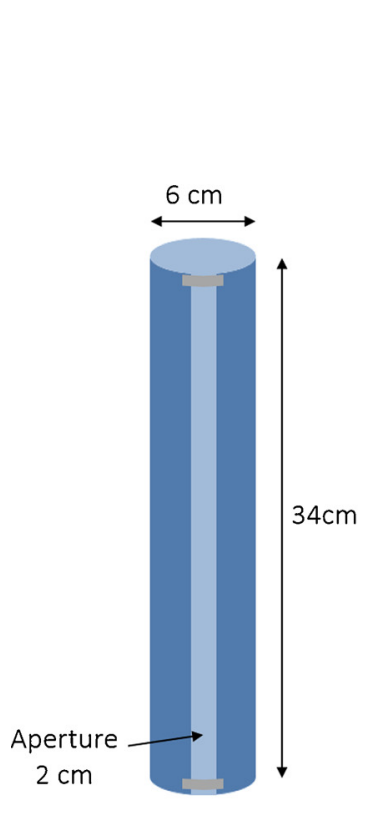

(a)

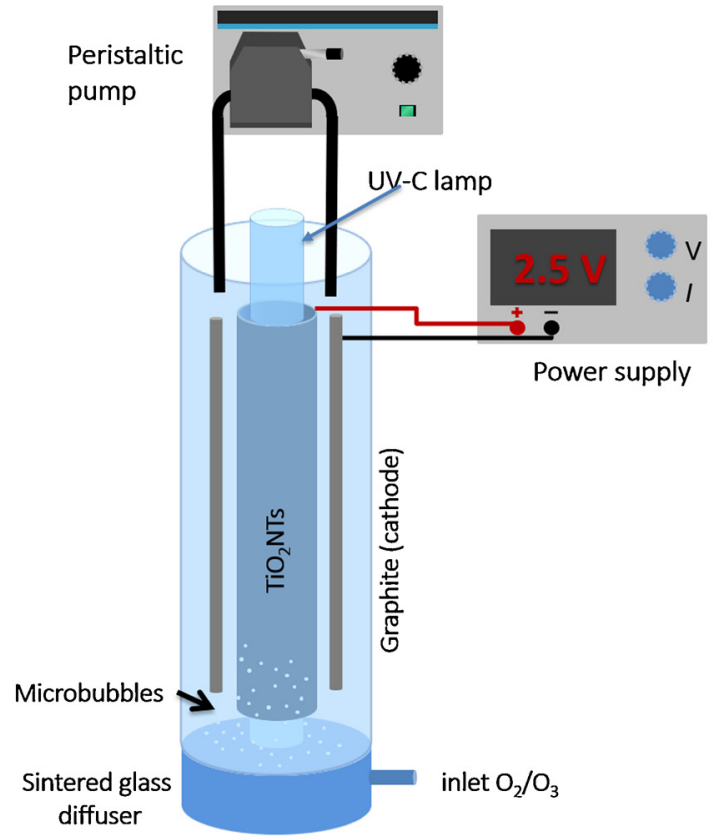

(b)

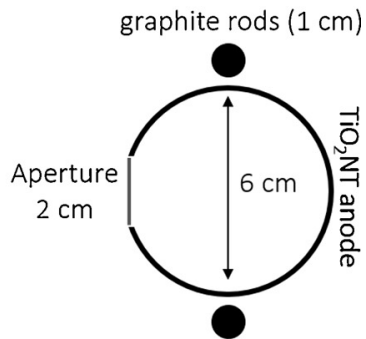

(c)

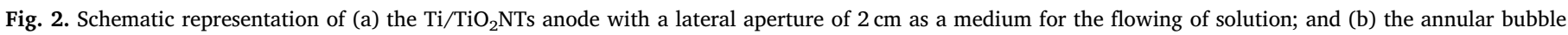

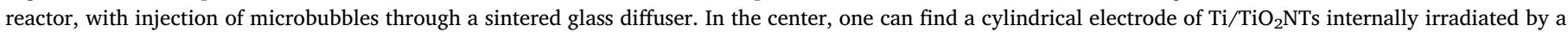

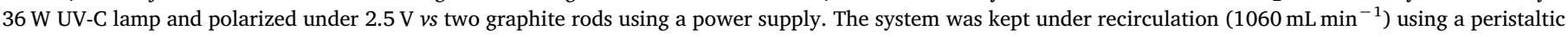
pump; (c) plan view of the electrode arrangement. 


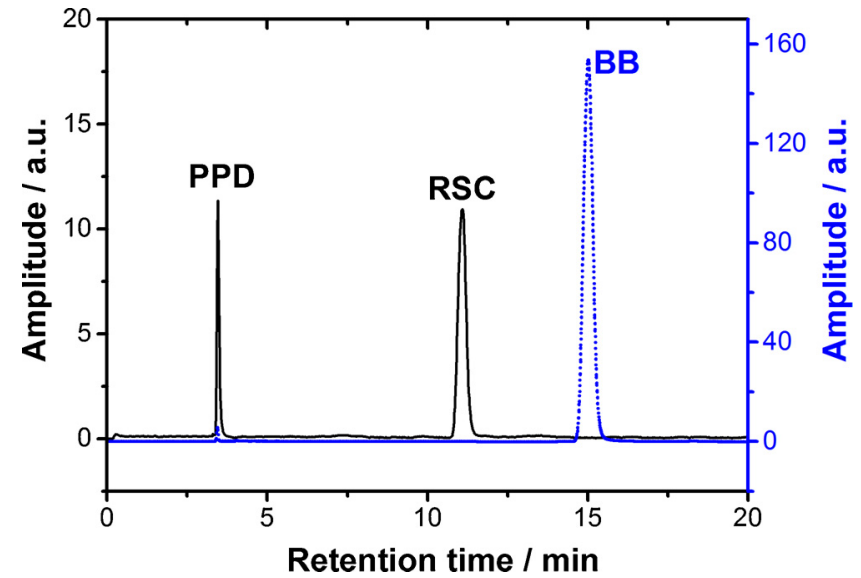

Fig. 3. Chromatogram by HPLC-DAD-UV/vis obtained for $10 \mathrm{mg} \mathrm{L}^{-1}$ of standard solution of $p$-phenylenediamine and resorcinol monitored at $279 \mathrm{~nm}$; and Bandrowski's base obtained from a $1000 \mathrm{mg} \mathrm{L}^{-1} p$-phenylenediamine solution in ammonia buffer (pH 8) with $1 \%$ hydrogen peroxide monitored at $413 \mathrm{~nm}$. Mobile phase acetate buffer of $0.1 \mathrm{~mol} \mathrm{~L}^{-1}$ (pH 5.6) and methanol, at flow rate of $0.80 \mathrm{~mL} \mathrm{~min}^{-1}$.

\subsection{Evaluation of hair dyeing effluent treatment by advanced oxidation processes}

A sample of the collected effluent $(1.3 \mathrm{~L})$ was transferred to the $\mathrm{ABR}$ and subjected to $90 \mathrm{~min}$ of treatment based on the aforementioned methodologies including ozonation $\left(\mathrm{O}_{3}\right)$, and the combination of oxidation processes namely $\mathrm{O}_{3}$ and UV-C light $\left(\mathrm{O}_{3} / \mathrm{UV}\right) ; \mathrm{O}_{3}$, UV-C and $\mathrm{H}_{2} \mathrm{O}_{2}\left(\mathrm{O}_{3} / \mathrm{PEC} / \mathrm{H}_{2} \mathrm{O}_{2}\right) ; \mathrm{O}_{3}$ and PEC $\left(\mathrm{O}_{3} / \mathrm{PEC}\right)$; and $\mathrm{O}_{3}$, PEC and $\mathrm{H}_{2} \mathrm{O}_{2}$ $\left(\mathrm{O}_{3} / \mathrm{PEC} / \mathrm{H}_{2} \mathrm{O}_{2}\right)$. The ozone was supplied at a flow rate of $3.85 \times 10^{-4} \mathrm{~mol} \mathrm{~min}^{-1}$. All the experiments with addition of hydrogen peroxide started with an initial concentration of $18 \mathrm{mmol} \mathrm{L}^{-1}$, which is equivalent to a TOC $/ \mathrm{H}_{2} \mathrm{O}_{2}$ dose ratio of 2.5 , in the same range as reported by other work [34]. The concentration of $\mathrm{H}_{2} \mathrm{O}_{2}$ during the treatment was monitored via the metavanadate method [35]. The aliquots taken during $90 \mathrm{~min}$ of degradation were analyzed by HPLC-DAD according to the preparation procedure described previously.

\subsection{Calculation of energy consumption: "Electric energy per order"}

Bolton et al. [31] have proposed standard figures of merit that allow the comparison of energy consumption irrespective of the nature of the system. While the nature of complexity of real wastewater makes it difficult if not cumbersome to know the exact composition and concentration of a specific compound, the concentration parameter can, nonetheless, be substituted by another parameter such as absorbance or TOC $[36,37]$. The first criterion for choosing the appropriate equation of energy consumption is the adjustment of the kinetic model. As the degradation kinetics of TOC follows approximately first-order kinetics, it is possible to apply the "electric energy per order" ( $E_{\mathrm{EO}}$, $\mathrm{kW} \mathrm{h} \mathrm{m}{ }^{-3}$ order $^{-1}$ ) (Eq. (1)), which can be defined as the electric energy in kilowatt hours $(\mathrm{kWh})$ required for degrading a contaminant by an order of magnitude in a unit volume $\left(1 \mathrm{~m}^{3}\right)$ :

$E_{E O}=\frac{P \times t \times 1000}{V \times \log \left(T O C_{i} / T O C_{f}\right)}$

where $P$ stands for the rated power (kW) of the oxidation system, $t$ being the treatment time $(\mathrm{h}), V$ the treated volume $(1.3 \mathrm{~L})$ and $T O C_{\mathrm{i}}$ and $T O C_{\mathrm{f}}$ representing the initial and final total organic carbon measurements $\left(\mathrm{mg} \mathrm{L}^{-1}\right)$. The rated power equals the sum of the energy consumption of the ozonator, the lamp and the power supply. The consumption of each piece of equipment (in $\mathrm{Wh}$ ) was calculated with the aid of multimeter measurements of current and utility voltage. The lamp, the power supply and the ozonator consume $36 \mathrm{~W} \mathrm{~h}, 8.7 \mathrm{~W} \mathrm{~h}$ and
$58.9 \mathrm{~W}$ h, respectively.

\section{Results and discussion}

\subsection{Physicochemical characteristics of hair dye effluent}

The physicochemical parameters evaluated for the collected hair dye effluent presented low conductivity $(164.0 \pm 1.4 \mu \mathrm{S})$, $\mathrm{pH}$ close to neutral $(7.31 \pm 0.12)$ and high levels of TOC $\left(169.4 \pm 0.72 \mathrm{mg} \mathrm{L}^{-1}\right)$, COD $\left(370 \pm 2 \mathrm{mg} \mathrm{L}^{-1}\right)$, color $(347.3 \pm 6.1 \mathrm{mg}$ PtCo/L) and turbidity $(64.83 \pm 2.5 \mathrm{NTU})$. Another striking feature is the intense foaming observed in the effluent which clearly unfolds new challenges in the quest for a suitable treatment. With the use of ozone-based treatment, for instance, the problem one notices is the gas bubbling that intensifies the foaming while decreasing the volume of liquid, thereby hampering gas/liquid interaction. The use of recirculation was deemed necessary as a result of the huge foaming caused by the solution bubbling, which was minimized by keeping the solution in flow. Similarly, as a result of the huge foaming, it was not possible to treat this effluent only by photo (electro)catalysis. The reason being that while photo(electro)catalysis presents high efficiency when it comes to TOC removal, it, however, exhibits low degradation kinetics which renders it impossible to oxidize surfactants in the first few minutes [24,27]. Hence, the foam formation is found to inhibit the generation of oxidizing species in solution regarded crucial for the degradation of organic compounds.

\subsection{Analysis of PPD, RSC and BB in the hair dye wastewater}

\subsubsection{Determination of the target compounds by HPLC-DAD}

The chemical pathways for the formation of Bandrowski's base along with the dye expected as the product of reaction between PPD and RSC in the oxidative medium were illustrated in Fig. 1 [38,8].

Fig. 3 shows a chromatogram obtained for $10 \mathrm{mg} \mathrm{L}^{-1}$ of standard solution of PPD and RSC samples at optimized conditions as described in the experimental section. PPD presented a well-defined peak at the retention time $\left(t_{R}\right)$ of $3.45 \mathrm{~min}$ and $R S C$ at $t_{R} 11.08 \mathrm{~min}$. Fig. 3 also shows the identification of Bandrowski's base, which is formed during unwanted reaction of PPD under an oxidative medium, such as ammonia buffer $(\mathrm{pH} 8)$, with $1 \%$ hydrogen peroxide in the presence of oxygen for $40 \mathrm{~min}[6,7]$. The chromatogram obtained for Bandrowski's base presented an intense peak at 15.3 min with high resolution when analyzed by HPLC-DAD using the optimized conditions of acetate buffer $0.1 \mathrm{~mol} \mathrm{~L}^{-1}(\mathrm{pH} \mathrm{5.6)}$ and methanol as mobile phase at a flow rate of $0.80 \mathrm{~mL} \mathrm{~min}^{-1}$ and detection at $413 \mathrm{~nm}$.

\subsection{Analysis of target compounds in the hair dye effluent}

Fig. 4a depicts the chromatograms obtained for hair dye effluent samples analyzed under the same conditions previously defined. The chromatogram obtained at $279 \mathrm{~nm}$ illustrates the presence of residues of $p$-phenylenediamine at $t_{R} 3.30 \mathrm{~min}$ and those of resorcinol at $t_{R}$ $11.05 \mathrm{~min}$ at concentrations of $0.058 \pm 0.02 \mathrm{mg} \mathrm{L}^{-1}$ and $4.52 \pm 0.17 \mathrm{mg} \mathrm{L}^{-1}$, respectively. The relatively low concentration of PPD is largely as a result of its ease of being oxidized to Bandrowski's base (Fig. 1) [7,39]. In the case of RSC, however, a relatively large concentration of its residue can be seen in the effluent, indicating that an excess of this compound used in the hair dyeing process failed to react in the hair fiber. It is noteworthy that even after three months of storage under refrigeration, the composition of the sample remained stable.

Fig. 4a illustrates the chromatogram of the hair dye effluent obtained at $413 \mathrm{~nm}$ which exhibits a high concentration of Bandrowski's base at $t_{R} 15.34$ min (the Bandrowski's base was not quantified since there is no standard besides the reaction being non-quantitative). Remarkably, these results raise great concerns to the extent that the literature categorizes $\mathrm{BB}$ as strong and potent sensitizers in animal tests 

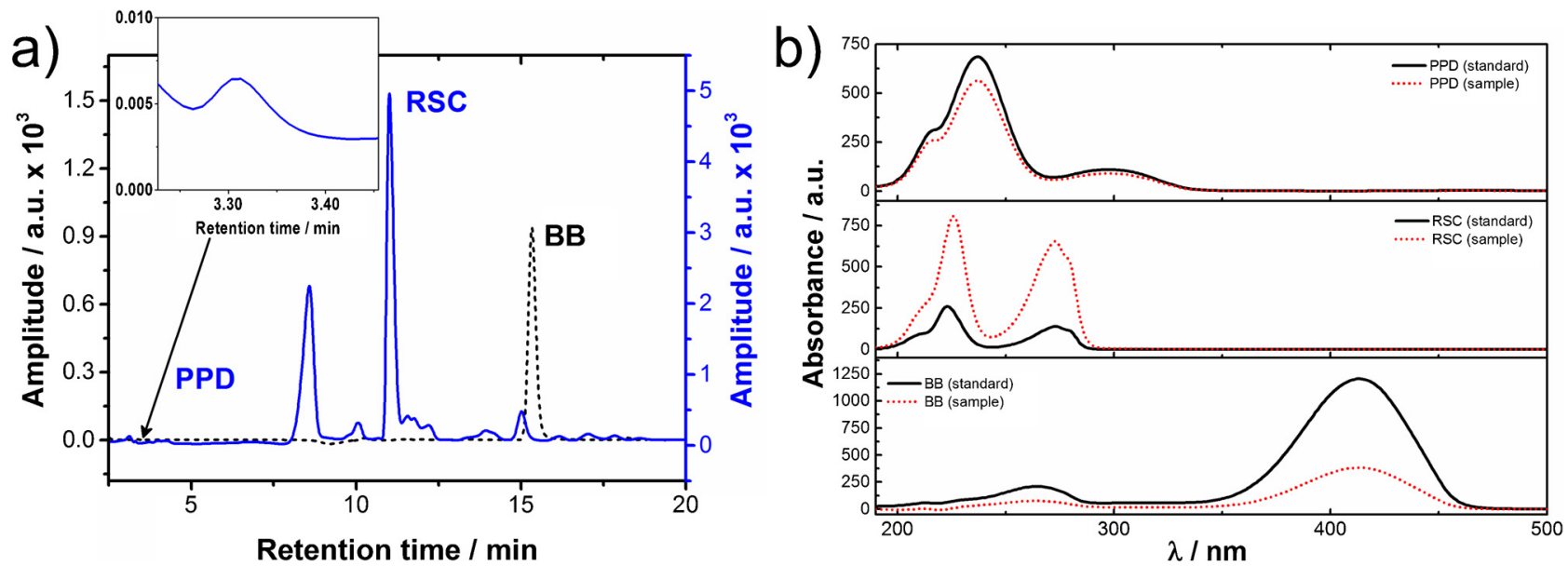

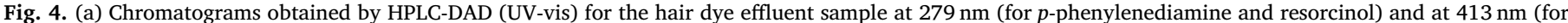

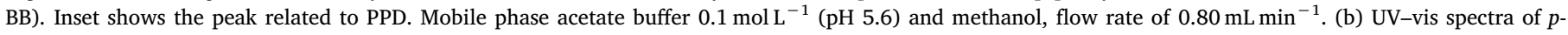

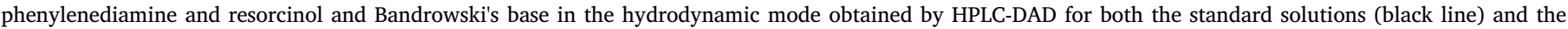
sample (red line).

involving topical exposure in addition to engendering the formation of reactive oxygen species $[6,40]$. Fig. $4 \mathbf{b}$ shows the UV-vis spectra for PPD, RSC and BB in the hydrodynamic mode obtained by HPLC-DAD (UV-vis) for both the standard solutions and the sample. The UV-vis spectra confirm that the substances in the chromatogram refer to the target compounds.

\subsection{Treatment of hair dye effluent by several oxidative processes}

A sample containing $1.3 \mathrm{~L}$ of the wastewater effluent was directly treated by the following processes: ozonation (input rate of $3.85 \times 10^{-4} \mathrm{~mol} \mathrm{~min}^{-1}$ and $\mathrm{O}_{2}$ flow rate of $1 \mathrm{~L} \mathrm{~min}^{-1}$ ), ozonation combined with UV-C light $\left(\mathrm{O}_{3} / \mathrm{UV}\right.$, UV-C $36 \mathrm{~W}$ lamp), ozonation with PEC $\left(\mathrm{O}_{3} / \mathrm{PEC}\right.$, voltage of $2.5 \mathrm{~V}$ using $\mathrm{TiO}_{2} \mathrm{NT}$ electrode irradiated by UV-C $36 \mathrm{~W}$ lamp), and ozonation with PEC and UV along with the addition of $18 \mathrm{mmol} \mathrm{L}{ }^{-1} \mathrm{H}_{2} \mathrm{O}_{2}\left(\mathrm{O}_{3} / \mathrm{UV} / \mathrm{H}_{2} \mathrm{O}_{2}\right.$ and $\left.\mathrm{O}_{3} / \mathrm{PEC} / \mathrm{H}_{2} \mathrm{O}_{2}\right)$. All the treatment processes were conducted without $\mathrm{pH}$ adjustment and recirculation rate of $1060 \mathrm{~L} \mathrm{~min}^{-1}$. The entire experiments were carried out within $90 \mathrm{~min}$ under recirculation and experimental conditions previously reported as ideal for hair dye degradation [24].

Fig. 5a, b show the time evolution of total organic carbon (TOC) and color removal during the treatment by different techniques. Ozonation showed a partial effluent decolorization (62\% after $90 \mathrm{~min}$ ) which is attributed to the oxidizing properties of ozone. Pure ozonation presented the lowest mineralization efficiency compared to the combined methods ( $48 \%$ after $90 \mathrm{~min}$ of treatment). This occurred because the selective attack on the double bonds generates by-products that cannot be easily degraded. A further observation worth mentioning has to do with the foaming process which ceased to occur in the first $3 \mathrm{~min}$ of treatment, indicating that ozone can attack surfactants compounds efficiently, allowing the treatment of the effluent to continue.

Guided by the aim of improving the results, the other treatment methodologies involving the combination of ozone with UV irradiation, ozone with photoelectrocatalysis, and ozone with hydrogen peroxide were investigated (Fig. 5). The foaming process was found to halt after $1.4 \mathrm{~min}, 1.0 \mathrm{~min}, 0.7$ and $0.6 \mathrm{~min}$ of treatment for $\mathrm{O}_{3} / \mathrm{UV}, \mathrm{O}_{3} / \mathrm{PEC}, \mathrm{O}_{3} /$ $\mathrm{UV} / \mathrm{H}_{2} \mathrm{O}_{2}$ and $\mathrm{O}_{3} / \mathrm{PEC} / \mathrm{H}_{2} \mathrm{O}_{2}$ treatment mechanisms, respectively.

The results obtained for ozone combined with UV-C irradiation presented a significantly higher efficiency, in as much as ozone can be converted to $\mathrm{H}_{2} \mathrm{O}_{2}$ and then to $\cdot \mathrm{OH}$ radicals, according to the following sequence of reactions (Eqs. (2)-(9)) [24,41,42].

$\mathrm{O}_{3}+\mathrm{H}_{2} \mathrm{O}+\mathrm{hv} \rightarrow \mathrm{H}_{2} \mathrm{O}_{2}+\mathrm{O}_{2}$

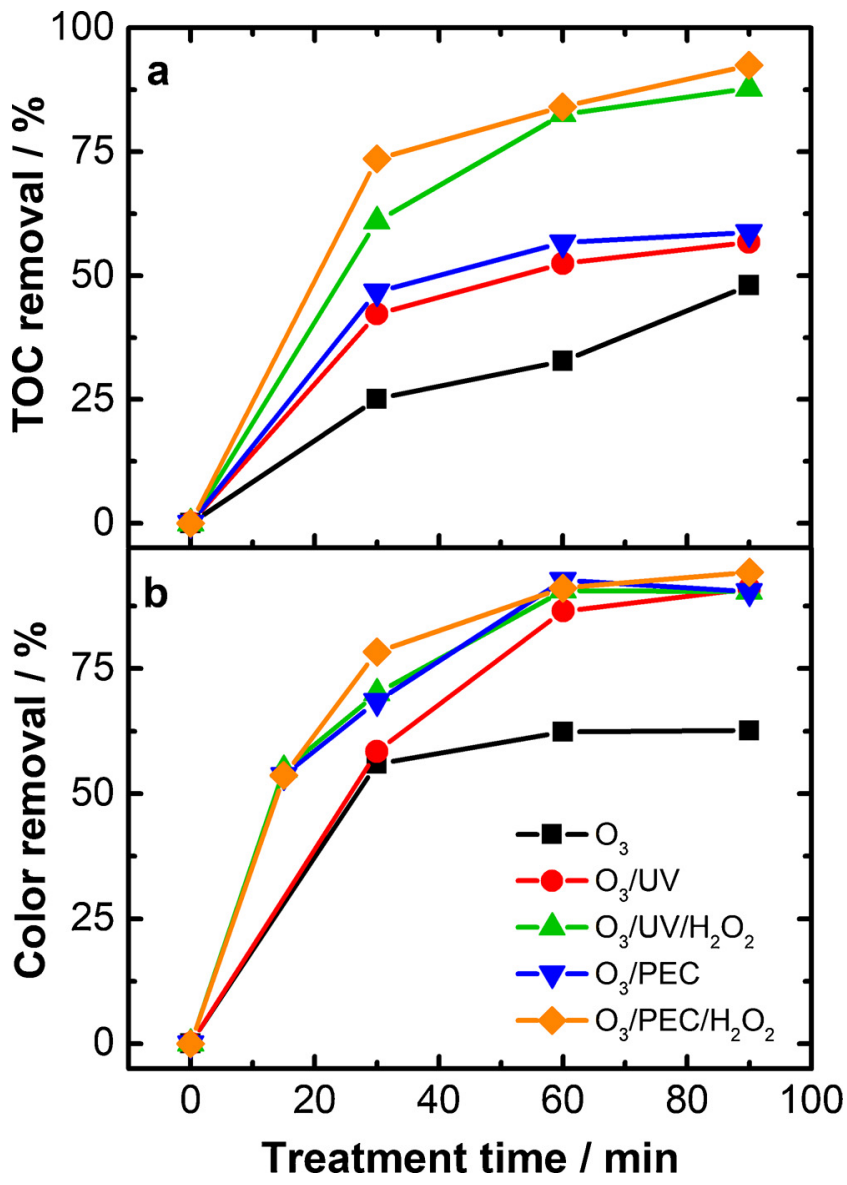

Fig. 5. (a) TOC removal (\%) and (b) color removal (\%) during the hair dye effluent treatment subjected to different combinations of AOPs. Conditions: ozone input rate of $3.85 \times 10^{-4} \mathrm{~mol} \mathrm{~min}^{-1}$ and $\mathrm{O}_{2}$ flow rate of $1 \mathrm{~L} \mathrm{~min}^{-1}$, voltage of $2.5 \mathrm{~V}$ using $\mathrm{TiO}_{2} \mathrm{NT}$ electrode, UV-C $36 \mathrm{~W}$ lamp, recirculation rate of $1060 \mathrm{~mL} \mathrm{~min}^{-1}$ and $18 \mathrm{mmol} \mathrm{L}^{-1} \mathrm{H}_{2} \mathrm{O}_{2}$.

$\mathrm{H}_{2} \mathrm{O}_{2}+\mathrm{hv} \rightarrow 2 \mathrm{OH}$.

$\mathrm{H}_{2} \mathrm{O}_{2} \leftrightarrows \mathrm{HO}_{2}^{-}+\mathrm{H}^{+}$

$\mathrm{O}_{3}+\mathrm{HO}_{2}^{-} \rightarrow \mathrm{O}_{3} \cdot{ }^{-}+\mathrm{HO}_{2}$. 
Table 1

Measured parameters for the hair dyeing effluent before and after $90 \mathrm{~min}$ of treatment by different techniques.

\begin{tabular}{|c|c|c|c|c|c|}
\hline Oxidation method & Conductivity $(\mu S)$ & Turbidity (NTU) ${ }^{\mathrm{a}}$ & $\mathrm{pH}$ & $\operatorname{COD}\left(\mathrm{mg} \mathrm{L}^{-1}\right)$ & {$\left[\mathrm{H}_{2} \mathrm{O}_{2}\right]\left(\mathrm{mmol} \mathrm{L}^{-1}\right)$} \\
\hline Initial & $164.0 \pm 1.4$ & $64.83 \pm 2.5$ & $7.31 \pm 0.12$ & $370 \pm 2$ & $18.3 \pm 0.2^{\mathrm{b}}$ \\
\hline $\mathrm{O}_{3}$ & $180.7 \pm 1.2$ & $18.4 \pm 0.45$ & $6.64 \pm 0.13$ & $108 \pm 2$ & - \\
\hline $\mathrm{O}_{3} / \mathrm{UV}$ & $182.3 \pm 0.94$ & $12.97 \pm 0.64$ & $4.38 \pm 0.10$ & $<50$ & - \\
\hline $\mathrm{O}_{3} / \mathrm{PEC}$ & $171.8 \pm 1.2$ & $5.49 \pm 0.18$ & $4.66 \pm 0.11$ & $<50$ & - \\
\hline $\mathrm{O}_{3} / \mathrm{UV} / \mathrm{H}_{2} \mathrm{O}_{2}$ & $182.3 \pm 1.5$ & $5.45 \pm 0.067$ & $4.38 \pm 0.10$ & $<50$ & $0.281 \pm 0.1$ \\
\hline $\mathrm{O}_{3} / \mathrm{PEC} / \mathrm{H}_{2} \mathrm{O}_{2}$ & $169.8 \pm 0.86$ & $8.97 \pm 0.095$ & $6.96 \pm 0.14$ & $<50$ & $<$ L.O.D. $^{\mathrm{c}}$ \\
\hline
\end{tabular}

Results of a triplicate.

a NTU: nephelometric turbidity units.

b added before starting treatment.

c L.O.D. $=0.138 \mathrm{mmol} \mathrm{L}^{-1}$.

$\mathrm{HO}_{2} \cdot \rightarrow \mathrm{O}_{2} \cdot{ }^{-}+\mathrm{H}^{+}$

$\mathrm{O}_{3}+\mathrm{O}_{2} \cdot{ }^{-} \rightarrow \mathrm{O}_{3} \cdot{ }^{-}+\mathrm{O}_{2}$

$\mathrm{O}_{3} \cdot{ }^{-}+\mathrm{H}^{+} \leftrightarrows \mathrm{HO}_{3} \cdot$

$\mathrm{HO}_{3} \cdot \rightarrow \mathrm{O}_{2}+\mathrm{OH} \cdot$

The combination of ozone with photoelectrocatalysis $\mathrm{O}_{3} / \mathrm{PEC}$ showed an improvement in decolorization and TOC removal. By virtue of the high turbidity (64.83 NTU) and color in hair dyeing effluents, a treatment based only on irradiation, such as photo(electro)catalysis, is essentially impracticable because of low penetration of light onto the surface of the photocatalyst. Thus, the use of ozonation in the treatment yields a partial improvement in the effluent decolorization performance as a result of the oxidizing properties of ozone. Furthermore, ozonation also helps the hydrodynamics of the process, ensuring a homogeneous mixture of the reaction medium and simultaneously promoting the breakdown of the main chemical bonds of organic compounds. In this sense, ozonation can provide a favorable environment for photoelectrocatalysis by facilitating the penetration of radiation from the light source to the photocatalyst surface. The combination of $\mathrm{O}_{3} / \mathrm{PEC}$ produces larger amounts of $\cdot \mathrm{OH}$ radicals through the photocatalytic conversion of $\mathrm{O}_{3}$ mediated by $\mathrm{TiO}_{2}$ (Eqs. (10)-(13)) [24,41]. This can be confirmed by observing the efficiency of decolorization/TOC removal (Fig. 5), where the $\mathrm{O}_{3} /$ PEC combination was the third most efficient technique.

$\mathrm{TiO}_{2}+\mathrm{hv} \rightarrow \mathrm{TiO}_{2}-\left(\mathrm{e}^{-}+\mathrm{h}^{+}\right)$

$\mathrm{O}_{3}+\mathrm{TiO}_{2}-\mathrm{e}^{-} \rightarrow \mathrm{O}_{3} \cdot-$

$\mathrm{O}_{3} \cdot{ }^{-}+\mathrm{H}^{+} \leftrightarrows \mathrm{HO}_{3} \cdot$

$\mathrm{HO}_{3} \cdot \rightarrow \mathrm{O}_{2}+\mathrm{OH} \cdot$

The combinations of $\mathrm{O}_{3} / \mathrm{UV}$ and $\mathrm{O}_{3} / \mathrm{PEC}$ along with the addition of $\mathrm{H}_{2} \mathrm{O}_{2}$ presented the highest color and TOC removal percentages. $\mathrm{H}_{2} \mathrm{O}_{2}$ is a very simple molecule yet with a complex chemical behavior in photocatalysis. It is a known fact that $\mathrm{TiO}_{2}$ photocatalysis requires a continuous $\mathrm{O}_{2}$ supply in order to minimize charge recombination, since $\mathrm{O}_{2}$ acts as a scavenger of photogenerated electrons. In this process, $\mathrm{O}_{2}$ is reduced by a sequence of reactions aiming at generating $\mathrm{H}_{2} \mathrm{O}_{2}$ (Eqs. (14)-(18)). In addition, $\mathrm{H}_{2} \mathrm{O}_{2}$ may be formed through the reaction of two $\cdot \mathrm{OH}$ radicals (Eq. 19) [43]:

$$
\begin{aligned}
& \mathrm{O}_{2}+\mathrm{e}^{-} \rightarrow \mathrm{O}_{2} \cdot{ }^{-} \\
& \mathrm{O}_{2} \cdot{ }^{-}+\mathrm{H}^{+} \rightarrow \mathrm{HO}_{2} \cdot \\
& \mathrm{HO}_{2} \cdot+\mathrm{e}^{-} \rightarrow \mathrm{HO}_{2}^{-} \\
& \mathrm{HO}_{2}^{-}+\mathrm{H}^{+} \rightarrow \mathrm{H}_{2} \mathrm{O}_{2} \\
& \mathrm{HO}_{2} \cdot+\mathrm{O}_{2} \cdot{ }^{-}+\mathrm{H}^{+} \rightarrow \mathrm{H}_{2} \mathrm{O}_{2}+\mathrm{O}_{2} \\
& \mathrm{OH} \cdot+\mathrm{OH} \cdot \rightarrow \mathrm{H}_{2} \mathrm{O}_{2}
\end{aligned}
$$

Taking into consideration that $\mathrm{H}_{2} \mathrm{O}_{2}$ can be decomposed into hydroxyl radicals by UV irradiation (Eq. (20)), or that it can be reduced by the photogenerated electrons in $\mathrm{TiO}_{2}$ (Eq. (21)), $\mathrm{H}_{2} \mathrm{O}_{2}$ is also likely to be oxidized by photogenerated holes (Eq. (22)) or by $\cdot \mathrm{OH}$ radicals (Eq. (23)) [43].

$\mathrm{H}_{2} \mathrm{O}_{2}+\mathrm{h} \nu \rightarrow \mathrm{OH} \cdot+\mathrm{OH} \cdot$

$\mathrm{H}_{2} \mathrm{O}_{2}+\mathrm{e}^{-} \rightarrow \mathrm{OH} \cdot+\mathrm{OH}^{-}$

$\mathrm{H}_{2} \mathrm{O}_{2}+\mathrm{h}^{+} \rightarrow \mathrm{HO}_{2} \cdot+\mathrm{H}^{+}$

$\mathrm{H}_{2} \mathrm{O}_{2}+\mathrm{OH} \cdot \rightarrow \mathrm{H}_{2} \mathrm{O}+\mathrm{HO}_{2} \cdot$

Apart from the reactions of $\mathrm{H}_{2} \mathrm{O}_{2}$ with $\mathrm{TiO}_{2}$, hydrogen peroxide can react with ozone (named peroxone process) to produce additional $\cdot \mathrm{OH}$ radicals (Eqs. (24)-(25)) [44,45].

$\mathrm{H}_{2} \mathrm{O}_{2}+\mathrm{H}_{2} \mathrm{O} \rightarrow \mathrm{HOO}^{-}+\mathrm{H}_{3} \mathrm{O}^{+}$

$\mathrm{HOO}^{-}+\mathrm{O}_{3} \rightarrow \mathrm{HO} \cdot+\mathrm{O}_{2} \cdot{ }^{-}+\mathrm{O}_{2}$

As such, the high production of $\cdot \mathrm{OH}$ radicals afforded by $\mathrm{H}_{2} \mathrm{O}_{2}$ (either by photolysis and reaction with ozone, or upon the photocatalytic decomposition of $\mathrm{H}_{2} \mathrm{O}_{2}$ ) explains the high percentage of mineralization achieved by $\mathrm{O}_{3} / \mathrm{UV} / \mathrm{H}_{2} \mathrm{O}_{2}$ and $\mathrm{O}_{3} / \mathrm{PEC} / \mathrm{H}_{2} \mathrm{O}_{2}$ combined advanced oxidation processes.

Table 1 compares the influence of each treatment on the turbidity, $\mathrm{pH}$, conductivity, COD removal and $\mathrm{H}_{2} \mathrm{O}_{2}$ concentration, after $90 \mathrm{~min}$ of treatment using the combinations of ozone, ozone with UV, ozone with photoelectrocatalysis, and ozone with hydrogen peroxide. The values of turbidity suffered a considerable decline from $64.83 \pm 2.5$ NTU to an acceptable limit of $4.66 \pm 0.11$ NTU for wastewater discharge. Microorganisms are typically attached to particulates, as such, the removal of turbidity will contribute towards reducing microbial contamination in treated water [46]. The high turbidity nature of salon wastewater could be largely attributed to the several chemical additives present in hair dye formulation such as surfactants, dyes, moisturizers, etc., which contain extensive carbon chains. Thus, the high decrease in turbidity likewise implies that this water treatment could be applied towards obtaining suitable water for domestic and recreational purposes.

The $\mathrm{pH}$ value is found to diminish to that of a slightly acidic solution $(\mathrm{pH}=4.66 \pm 0.11)$. This reduction can be attributed to the generation of both organic acids and $\mathrm{H}^{+}$from water oxidation aiming at the generation of $\cdot \mathrm{OH}$ radicals $\left(\mathrm{TiO}_{2} \mathrm{~h}^{+}+\mathrm{H}_{2} \mathrm{O} \rightarrow \mathrm{OH} \cdot+\mathrm{H}^{+}\right)$. However, conductivity is seen to be almost constant over the treatment duration. A significant difference was obtained for COD removal which decreased from $370 \pm 2 \mathrm{mg} \mathrm{L}^{-1}$ to values lower than $50 \mathrm{mg} \mathrm{L}^{-1}$ after $90 \mathrm{~min}$ of treatment for all the treatment techniques under investigation, with the exception of ozonation by which the decrease in COD removal was found to be less pronounced.

Another observation worth pointing out is the decrease observed in the $\mathrm{H}_{2} \mathrm{O}_{2}$ concentration to a level below the limit of detection for the 

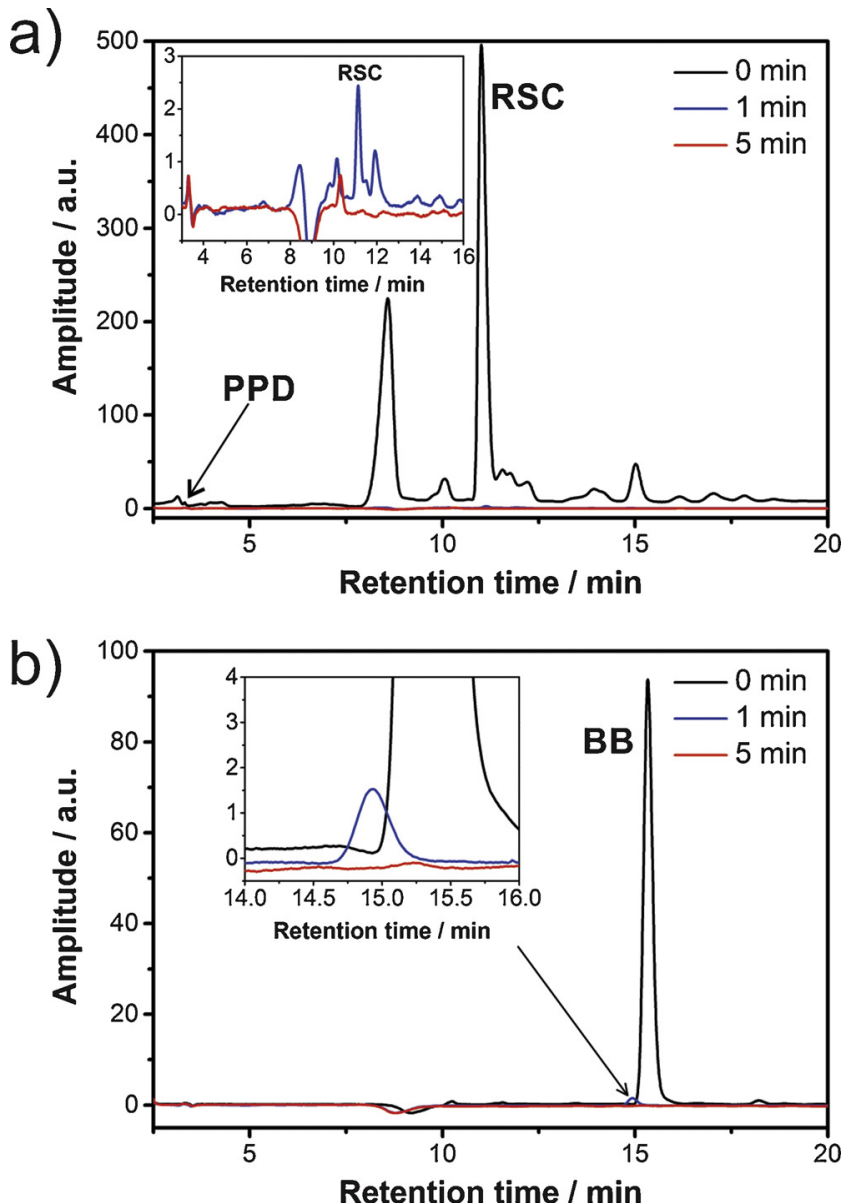

Fig. 6. (a) Chromatograms of hair dye effluent at $279 \mathrm{~nm}$ obtained by HPLCDAD-UV/vis, showing $p$-phenylenediamine (at $t_{R}=3.3 \mathrm{~min}$ ) and resorcinol (at $\mathrm{t}_{\mathrm{R}}=11.05 \mathrm{~min}$ ) before and after $\mathrm{O}_{3} / \mathrm{PEC} / \mathrm{H}_{2} \mathrm{O}_{2}$ treatment for 1 and $5 \mathrm{~min}$; and (b) chromatograms of hair dye effluent at $413 \mathrm{~nm}$, showing Bandrowski's base at $t_{R}$ of $15.34 \mathrm{~min}$, before and after $\mathrm{O}_{3} / \mathrm{PEC} / \mathrm{H}_{2} \mathrm{O}_{2}$ treatment for 1 and $5 \mathrm{~min}$. $\mathrm{O}_{3} / \mathrm{PEC} / \mathrm{H}_{2} \mathrm{O}_{2}$ conditions: ozone input rate of $3.85 \times 10^{-4} \mathrm{~mol} \mathrm{~min}^{-1}$ and $\mathrm{O}_{2}$ flow rate of $1 \mathrm{~L} \mathrm{~min}^{-1}$, voltage of $2.5 \mathrm{~V}$ using $\mathrm{TiO}_{2} \mathrm{NT}$ electrode, UV-C $36 \mathrm{~W}$ lamp, recirculation at a rate of $1060 \mathrm{~mL} \mathrm{~min}^{-1}$ and $18 \mathrm{mmol} \mathrm{L}^{-1} \mathrm{H}_{2} \mathrm{O}_{2}$.

combined process of $\mathrm{O}_{3} / \mathrm{PEC} / \mathrm{H}_{2} \mathrm{O}_{2}$. The monitoring of $\mathrm{H}_{2} \mathrm{O}_{2}$ is deemed relevant to dose the initial concentration of this reagent without excessive costs besides ensuring that a possible excess does not contribute negatively in the treatment process, since $\mathrm{H}_{2} \mathrm{O}_{2}$ can act as a scavenger of holes and $\cdot \mathrm{OH}$ radicals.

Fig. 6 shows that PPD, RSC and $\mathrm{BB}$ occurred in the effluent only after 1 and 5 min of $\mathrm{O}_{3} / \mathrm{PEC} / \mathrm{H}_{2} \mathrm{O}_{2}$ treatment. All the chromatographic signals of these harmful compounds were eliminated after $5 \mathrm{~min}$ of treatment. Furthermore, the other peaks present in the chromatograms and not identified previously also decreased significantly. There is no formation of new peaks, indicating that there is no formation of undesirable sub- products (that can be detected under these chromatographic conditions), thus it is very unlikely that by-products could be present in longer treatment times. This might suggest the effectiveness of the treatment technique to reduce the possible toxicity of hair dye effluent and to eliminate components with carcinogenic potential that could bioaccumulate and cause harmful effects to the environment.

\subsection{Assessment of energy consumption: "Electric energy per order"}

Energy consumption represents the largest operation cost of effluents treatment via advanced oxidation processes [31,47]. In this way, we have employed the concept of "electric energy per order" $\left(E_{\mathrm{EO}}\right.$,

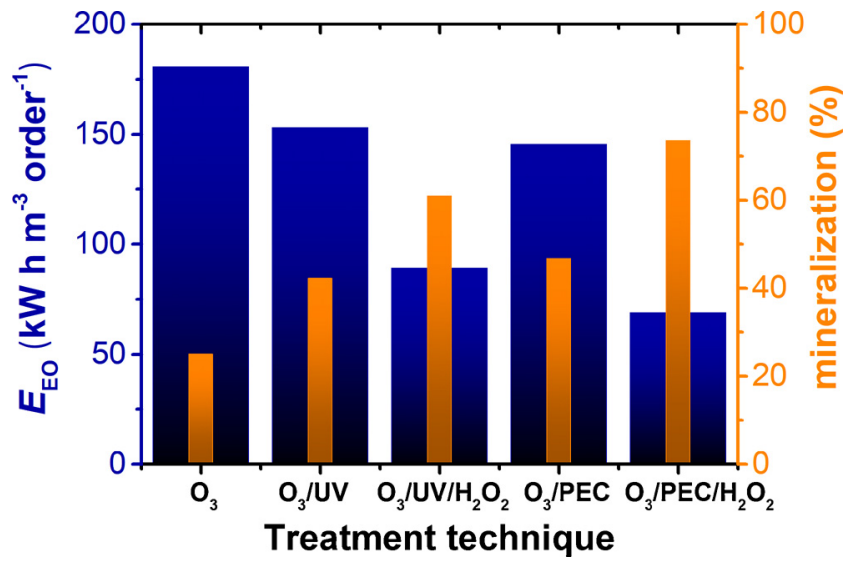

Fig. 7. Figure of merit (electric energy per order, $E_{\mathrm{EO}} / \mathrm{kW} \mathrm{h} \mathrm{m}^{-3}$ order $^{-1}$ ) for the different techniques applied in the advanced treatment (for $30 \mathrm{~min}$ ) of hair dye effluent in comparison and contrast to mineralization efficiency (\%) (Blue wide bars refer to $E_{\mathrm{EO}}$ and orange narrow bars refer to \% mineralization).

$\mathrm{kW} \mathrm{h} \mathrm{m}^{-3}$ order $^{-1}$ ) (Eq. (25)) proposed by Bolton et al. [31] (defined in Section 2.5). Taking $30 \mathrm{~min}$ as the treatment time for the calculation of $E_{\mathrm{EO}}$, Fig. 7 shows the $E_{\mathrm{EO}}$ values for the different oxidation systems. Fig. 7 also shows the amount of mineralization (\%) for comparison with $E_{\mathrm{EO}}$, since it is not possible to assess the TOC removal efficiency through isolated $E_{\mathrm{EO}}$ values.

Thus, it is noteworthy that the lowest energy consumption values $\left(E_{\mathrm{EO}}\right)$ are obtained through techniques that make use of $\mathrm{H}_{2} \mathrm{O}_{2}$ which are also blended with higher effluent mineralization rates. However, for a large-scale design, it is essentially necessary to consider the $\mathrm{H}_{2} \mathrm{O}_{2}$ costs, since $E_{\mathrm{EO}}$ expresses only the energy consumption. The combination $\mathrm{O}_{3} /$ $\mathrm{PEC} / \mathrm{H}_{2} \mathrm{O}_{2}$ presented the lowest value of $E_{\mathrm{EO}}$ and highest percentage of mineralization as a result of the catalytic decomposition of $\mathrm{H}_{2} \mathrm{O}_{2}$ to hydroxyl radicals. This decomposition is prompted by the $\mathrm{TiO}_{2}$ and does not occur in the $\mathrm{O}_{3} / \mathrm{UV} / \mathrm{H}_{2} \mathrm{O}_{2}$ system (Eqs. (21), (22)). Among the techniques without $\mathrm{H}_{2} \mathrm{O}_{2}$, the combination $\mathrm{O}_{3}$ /PEC presented a slightly lower $E_{\mathrm{EO}}$ value and higher percentage of mineralization, thus reinforcing the discussion of the synergistic mechanisms of this combination.

\section{Conclusions}

Hair dye wastewater is characterized by intense color, high turbidity, in addition to high TOC and COD contents. The chromatographic analysis of this wastewater also demonstrates the presence of large amounts of color precursors (such as PPD and RSC) that remain unreacted, and an undesirable mutagenic by-product - the Bandrowski's base, which can be potentially dangerous once released into surface waters. The results show that hair salon wastewater can fairly be characterized as potential public and environmental health hazard. Techniques based on ozone, photoelectrocatalysis, UV-C and $\mathrm{H}_{2} \mathrm{O}_{2}$ alone were found to be ineffective when it comes to decreasing the wastewater physicochemical parameters to acceptable limits for the reutilization of the water. Interestingly, the combination of $\mathrm{O}_{3} / \mathrm{PEC} /$ $\mathrm{H}_{2} \mathrm{O}_{2}$ presented low electric energy per order and highest mineralization rate, being capable of degrading PPD, RSC and BB completely in less than $5 \mathrm{~min}$. This same combination was also found to eliminate all the unidentified compounds occurring as peaks in the chromatograms, without apparently forming new degradation products. The fact that $42 \%$ of women and $25 \%$ of men make use of hair dyes raises huge environmental and public health concerns as large amounts of contaminants from the residues of these hair dyes may find their way into surface waters or sewage stations. In this context, our findings are an important step towards the elaboration of an efficient and simple method for the treatment of complex wastewater. 


\section{Declarations of interest}

None.

\section{Acknowledgements}

The authors are grateful to the Brazilian Research Agencies: Fundação de Amparo à Pesquisa do Estado de São Paulo - FAPESP (grant numbers 2014/03679-7, 2015/12998-1 and 2015/18109-4) and Conselho Nacional de Desenvolvimento Científico e Tecnológico CNPq (grant numbers 152274/2016-2 and 446245/2014-3), for the financial support granted in the course of this research.

\section{References}

1] M.S. Reisch, Flush with color: continuing progress in hair dye chemistry satisfies diverse desires of young and old, Chem. Eng. News 81 (2003) 25-27, http://dx.doi. org/10.1021/cen-v081n009.p025.

[2] Y. Tafurt-Cardona, P. Suares-Rocha, T.C.C. Fernandes, M.A. Marin-Morales, Cytotoxic and genotoxic effects of two hair dyes used in the formulation of black color, Food Chem. Toxicol. 86 (2015) 9-15, http://dx.doi.org/10.1016/j.fct.2015. 09.010.

[3] O.J.X. Morel, R.M. Christie, Current trends in the chemistry of permanent hair dyeing, Chem. Rev. 111 (2011) 2537-2561, http://dx.doi.org/10.1021/cr1000145.

[4] J.F. Corbett, Hair Colorants: Chemistry and Toxicology, Micelle Press, Weymouth, 1998.

[5] G.J. Nohynek, R. Fautz, F. Benech-kieffer, H. Toutain, Toxicity and human health risk of hair dyes, Food Chem. Toxicol. 42 (2004) 517-543, http://dx.doi.org/10. 1016/j.fct.2003.11.003.

[6] T.B. Zanoni, F. Hudari, A. Munnia, M. Peluso, R.W. Godschalk, M.V.B. Zanoni, G.J.M. den Hartog, A. Bast, S.B.M. Barros, S.S. Maria-Engler, G.J. Hageman, D.P. de Oliveira, The oxidation of $p$-phenylenediamine, an ingredient used for permanent hair dyeing purposes, leads to the formation of hydroxyl radicals: oxidative stress and DNA damage in human immortalized keratinocytes, Toxicol. Lett. 239 (2015) 194-204, http://dx.doi.org/10.1016/j.toxlet.2015.09.026.

[7] F.F. Hudari, L.C. de Almeida, B.F. da Silva, M.V.B. Zanoni, Voltammetric sensor for simultaneous determination of $p$-phenylenediamine and resorcinol in permanent hair dyeing and tap water by composite carbon nanotubes/chitosan modified electrode, Microchem. J. 116 (2014) 261-268, http://dx.doi.org/10.1016/j.microc. 2014.05.007.

[8] M.J. Shah, W.S. Tolgyesi, A.D. Britt, Cooxidation of $p$-phenylenediamine and resorcinol in hair dyes, J. Soc. Cosmet. Chem. 23 (1972) 853-861 http://journal. scconline.org/abstracts/cc1972/cc023n13/p00853-p00861.html.

[9] J.F. Corbett, An historical review of the use of dye precursors in the formulation of commercial oxidation hair dyes, Dye. Pigm. 41 (1999) 127-136, http://dx.doi.org/ 10.1016/S0143-7208(98)00075-8.

[10] D. Hamann, K. Yazar, C.R. Hamann, J.P. Thyssen, C. Lidén, p-phenylenediamine and other allergens in hair dye products in the United States: a consumer exposure study, Contact Dermat. 70 (2014) 213-218, http://dx.doi.org/10.1111/cod.12164.

[11] J.M.L. White, P. Kullavanijaya, I. Duangdeeden, R. Zazzeroni, N.J. Gilmour, D.A. Basketter, J.P. McFadden, p-phenylenediamine allergy: the role of Bandrowski's base, Clin. Exp. Allergy 36 (2006) 1289-1293, http://dx.doi.org/10. 1111/j.1365-2222.2006.02561.x.

[12] J. Spengler, M. Bracher, Toxicological tests and health risk assessment of oxidative hair dye mixtures, Cosmet. Toilet. 105 (1990) 67-76.

[13] T. Watanabe, T. Hirayama, S. Fukui, The mutagenic modulating effect of $p$-phenylenediamine on the oxidation of $o$ - or $m$-phenylenediamine with hydrogen peroxide in the Salmonella test, Mutat. Res. Lett. 245 (1990) 15-22, http://dx.doi.org/ 10.1016/0165-7992(90)90019-G.

[14] G.E. Parris, Environmental and metabolic transformations of primary aromatic amines and related compounds, Residue Rev. 76 (1980) 1-30, http://dx.doi.org/10. 1007/978-1-4612-6107-0 1.

[15] B. Petrie, R. Barden, B. Kasprzyk-Hordern, A review on emerging contaminants in wastewaters and the environment: current knowledge, understudied areas and recommendations for future monitoring, Water Res. 72 (2014) 3-27, http://dx.doi. org/10.1016/j.watres.2014.08.053.

[16] I. Tamura, K. Kagota, Y. Yasuda, S. Yoneda, J. Morita, N. Nakada, Y. Kameda, K. Kimura, N. Tatarazako, H. Yamamoto, Ecotoxicity and screening level ecotoxicological risk assessment of five antimicrobial agents: triclosan, triclocarban, resorcinol, phenoxyethanol and p-thymol, J. Appl. Toxicol. 33 (2013) 1222-1229, http://dx.doi.org/10.1002/jat.2771.

[17] N. Bolong, A.F. Ismail, M.R. Salim, T. Matsuura, A review of the effects of emerging contaminants in wastewater and options for their removal, Desalination 239 (2009) 229-246, http://dx.doi.org/10.1016/j.desal.2008.03.020.

[18] I.M. Bryant, R. Tetteh-Narh, Using slow sand filtration system with activated charcoal layer to treat salon waste water in a selected community in Cape Coast, Ghana, Adv. Chem. Eng. 5 (2016) 2090-4568, http://dx.doi.org/10.4172/2090-
4568.1000135.

[19] C.R. Bartels, M. Wilf, K. Andes, J. Iong, Design considerations for wastewater treatment by reverse osmosis, Water Sci. Technol. 51 (2005) 473-482 (Accessed 18 May 2017), http://www.ncbi.nlm.nih.gov/pubmed/16004010.

[20] M.N. Rashed, Adsorption technique for the removal of organic pollutants from water and wastewater, in: Mohamed Nageeb Rashed (Ed.), Org. Pollut. - Monit. Risk Treat. InTech, Rijeka, 2018, , http://dx.doi.org/10.5772/54048.

[21] C.S. Slater, R.C. Ahlert, C.G. Uchrin, Applications of reverse osmosis to complex industrial wastewater treatment, Desalination 48 (1983) 171-187, http://dx.doi. org/10.1016/0011-9164(83)80015-0.

[22] Water Environment Federation, American Water Works Association, Standard Methods for the Examination of Water and Wastewater, American Public Health Association, Washington, DC, 1999.

[23] T. Asano, Water Reuse: Issues, Technologies, and Applications, McGraw Hill, New York, 2003.

[24] G.G. Bessegato, J.C. Cardoso, B.F. da Silva, M.V.B. Zanoni, Combination of photoelectrocatalysis and ozonation: a novel and powerful approach applied in Acid Yellow 1 mineralization, Appl. Catal. B Environ. 180 (2016) 161-168, http://dx. doi.org/10.1016/j.apcatb.2015.06.013.

[25] G.G. Bessegato, J.C. Cardoso, B.F. Silva, M.V.B. Zanoni, Enhanced photoabsorption properties of composites of $\mathrm{Ti} / \mathrm{TiO}_{2}$ nanotubes decorated by Sb2S3 and improvement of degradation of hair dye, J. Photochem. Photobiol. A Chem. 276 (2013) 96-103, http://dx.doi.org/10.1016/j.jphotochem.2013.12.001.

[26] G.G. Bessegato, J.C. Cardoso, M.V.B. Zanoni, Enhanced photoelectrocatalytic degradation of an acid dye with boron-doped $\mathrm{TiO}_{2}$ nanotube anodes, Catal. Today 240 (2014) 100-106, http://dx.doi.org/10.1016/j.cattod.2014.03.073.

[27] G.G. Bessegato, T.T. Guaraldo, J.F. de Brito, M.F. Brugnera, M.V.B. Zanoni, Achievements and trends in photoelectrocatalysis: from environmental to energy applications, Electrocatalysis 6 (2015) 415-441, http://dx.doi.org/10.1007/ s12678-015-0259-9.

[28] M. Mehrjouei, S. Müller, D. Möller, A review on photocatalytic ozonation used for the treatment of water and wastewater, Chem. Eng. J. 263 (2015) 209-219, http:// dx.doi.org/10.1016/j.cej.2014.10.112.

[29] S.Z. Ahammad, A. Yakubu, J. Dolfing, C. Mota, D.W. Graham, Feasibility tests for treating shampoo and hair colorant wastewaters using anaerobic processes, Water Sci. Technol. 65 (2012) 303-308.

[30] J. Yin, Y. Hu, Study on hair dyeing wastewater treatment by the union process of adsorption coagulation and potassium permanganate oxide, Appl. Mech. Mater. 638 (2014) 638-642, http://dx.doi.org/10.4028/www.scientific.net/AMM.675-677. 638.

[31] J.R. Bolton, K.G. Bircher, W. Tumas, C.A. Tolman, Figures-of-merit for the technical development and application of advanced oxidation technologies for both electricand solar-driven systems (IUPAC Technical Report), Pure Appl. Chem. 73 (2001) 627-637, http://dx.doi.org/10.1351/pac200173040627.

[32] M. Narita, K. Murakami, J.-M. Kauffmann, Determination of dye precursors in hair coloring products by liquid chromatography with electrochemical detection, Anal. Chim. Acta 588 (2007) 316-320, http://dx.doi.org/10.1016/j.aca.2007.02.023.

[33] J.C. Cardoso, T.M. Lizier, M.V.B. Zanoni, Highly ordered $\mathrm{TiO}_{2}$ nanotube arrays and photoelectrocatalytic oxidation of aromatic amine, Appl. Catal. B Environ. 99 (2010) 96-102, http://dx.doi.org/10.1016/j.apcatb.2010.06.005.

[34] M.S. Lucas, J.A. Peres, G. Li Puma, Treatment of winery wastewater by ozone-based advanced oxidation processes $(\mathrm{O} 3, \mathrm{O} 3 / \mathrm{UV}$ and $\mathrm{O} 3 / \mathrm{UV} / \mathrm{H} 2 \mathrm{O} 2)$ in a pilot-scale bubble column reactor and process economics, Sep. Purif. Technol. 72 (2010) 235-241, http://dx.doi.org/10.1016/j.seppur.2010.01.016.

[35] R.F.P. Nogueira, M.C. Oliveira, W.C. Paterlini, Simple and fast spectrophotometric determination of $\mathrm{H} 2 \mathrm{O} 2$ in photo-Fenton reactions using metavanadate, Talanta 66 (2005) 86-91, http://dx.doi.org/10.1016/j.talanta.2004.10.001.

[36] J.C. Cardoso, G.G. Bessegato, M.V.B. Zanoni, Efficiency comparison of ozonation, photolysis, photocatalysis and photoelectrocatalysis methods in real textile wastewater decolorization, Water Res. 98 (2016) 39-46, http://dx.doi.org/10.1016/j. watres.2016.04.004.

[37] G.R.P. Malpass, D.W. Miwa, D.A. Mortari, S.A.S. Machado, A.J. Motheo, Decolorisation of real textile waste using electrochemical techniques: effect of the chloride concentration, Water Res. 41 (2007) 2969-2977, http://dx.doi.org/10. 1016/j.watres.2007.02.054.

[38] G.J. Nohynek, E. Antignac, T. Re, H. Toutain, Safety assessment of personal care products/cosmetics and their ingredients, Toxicol. Appl. Pharmacol. 243 (2010) 239-259, http://dx.doi.org/10.1016/j.taap.2009.12.001.

[39] R.A.G. de Oliveira, T.B. Zanoni, G.G. Bessegato, D.P. Oliveira, G.A. Umbuzeiro, M.V.B. Zanoni, The chemistry and toxicity of hair dyes, Quim. Nova 37 (2014) 1037-1046, http://dx.doi.org/10.5935/0100-4042.20140143.

[40] E.V. Warbrick, R.J. Dearman, L.J. Lea, D.A. Basketter, I. Kimber, Local lymph node assay responses to paraphenylenediamine: intra- and inter-laboratory evaluations, J. Appl. Toxicol. 19 (1999) 255-260, http://dx.doi.org/10.1002/(SICI)1099 1263(199907/08)19:4 < 255:AID-JAT573>3.0.CO;2-S.

[41] T.E. Agustina, H.M. Ang, V.K. Vareek, A review of synergistic effect of photocatalysis and ozonation on wastewater treatment, J. Photochem. Photobiol. C Photochem. Rev. 6 (2005) 264-273, http://dx.doi.org/10.1016/j.jphotochemrev 2005.12.003.

[42] J. Xiao, Y. Xie, H. Cao, Organic pollutants removal in wastewater by heterogeneous photocatalytic ozonation, Chemosphere 121 (2015) 1-17, http://dx.doi.org/10. 1016/j.chemosphere.2014.10.072. 
[43] K. Sahel, L. Elsellami, I. Mirali, F. Dappozze, M. Bouhent, C. Guillard, Hydrogen peroxide and photocatalysis, Appl. Catal. B Environ. 188 (2016) 106-112, http:// dx.doi.org/10.1016/j.apcatb.2015.12.044.

[44] J. Staehelin, J. Hoigne, Decomposition of ozone in water: rate of initiation by hydroxide ions and hydrogen peroxide, Environ. Sci. Technol. 16 (1982) 676-681, http://dx.doi.org/10.1021/es00104a009.

[45] G. Merényi, J. Lind, S. Naumov, C. Von Sonntag, Reaction of ozone with hydrogen peroxide (peroxone process): a revision of current mechanistic concepts based on thermokinetic and quantum-chemical considerations, Environ. Sci. Technol. 44
(2010) 3505-3507, http://dx.doi.org/10.1021/es100277d.

[46] World Health Organization, Guidelines for Drinking-water Quality, 4th ed., World Health Organization, Geneva, 2011http://apps.who.int/iris/bitstream/10665/ 44584/1/9789241548151_eng.pdf.

[47] M. Mehrjouei, S. Müller, D. Möller, Catalytic and photocatalytic ozonation of tertbutyl alcohol in water by means of falling film reactor: kinetic and cost-effectiveness study, Chem. Eng. J. 248 (2014) 184-190, http://dx.doi.org/10.1016/j.cej. 2014.03.047. 